\title{
Cardiovascular risk factors encountered during medical examination in athletic children
}

\author{
Adela C. Cis Spoturno, M.D. ', María T. Paz-Sauquillo, M.D. ${ }^{b}$, \\ Matilde López-Zea, M.D. ${ }^{a}$, and Eduardo A. Fernández-Rostello, M.D.
}

\begin{abstract}
Cardiovascular risk factors can predispose to cardiovascular disease in adults or lead to cardiovascular events while practicing sports. The objectives of this study were: 1 ) to estimate the distribution of individual cardiovascular risk factors; 2) to establish a relationship between cardiovascular risk factors in parents or grandparents and the children's clinical condition.

This was a retrospective study to assess overweight, obesity and hypertension in 1021 child athletes. The family history of obesity, type 2 diabetes, ischemic heart disease, and stroke was studied. Out of the studied children, $22.1 \%(n=226)$ were obese and $2.1 \%(n=21)$ had hypertension. Obesity was the most common family risk factor (30\%).

Key words: athletic children, cardiovascular risk factors, family members.
\end{abstract}

http:/ /dx.doi.org/10.5546/aap.2013.472

\section{INTRODUCTION}

The presence of certain individual

a. Cedena. Division of Cardiology and Sports Medicine . Centro de Evaluación de Niños y Adolescentes Deportistas. Almería, Spain

b. IDM. Sports Medicine Department. Instituto Deportivo Municipal. Cantabria, Spain.

c. Department of Teaching and Research Hospital Bernardino Rivadavia. Buenos Aires, Argentine.

E-mail Address:

Adela Cis Spoturno, M.D.: a.cristina353@ gmail.com

Conflict of Interest: None.

Received: 11-22-2012 Accepted: 6-10-2013 the onset of cardiovascular events while practicing a sport. ${ }^{4-9}$

The objectives were to estimate the distribution of ICVRFs in a specific population of young athletes and to establish the relationship between the presence of risk factors in parents or grandparents and the children's clinical condition.

\section{MATERIAL AND METHODS}

This was a retrospective review of the medical records of children and adolescents who completed a sports physical exam. Subjects were evaluated in two medical facilities, between 2005 and 2008, as follows: the Municipal Sports Institute (Instituto Deportivo Municipal, IDM) in Santoña (Cantabria) and the Center for Assessment of Athletic Children and Adolescents (Centro de Evaluación de Niños y Adolescentes Deportistas, CEDENA), in Almería (Andalucía). Inclusion criteria were: 1) to practice sports regularly and for more than 4 hours a week, 2) to take part in competitions, and 3) to be registered in their corresponding leagues. The presence of a disease was not an exclusion criterion.

The study was approved by the External Independent Ethics Committee of Clínica Mediterráneo (Almería, Spain) before its initiation.

A global consecutive sample was structured with all patients examined in both sites.

All medical records were analyzed taking into consideration the limitations related to data recording in retrospective studies. Both sites described similar standard sports physical exams and estimations of anthropometric outcome measures: the patient is examined in his/her 
underwear, barefoot and standing. Weight was measured in kilograms using SECA mechanical scales; height was measured in meters, with the subject's head adjusted to the Frankfurt plane and using a stadiometer attached to the scale, and the body mass index (BMI) was calculated using the Quetelet index (weight/height ${ }^{2}$ ).

Systolic and diastolic blood pressure measurements were recorded using an auscultatory method, with Korotkoff's phase 1 and 5 sounds, respectively. The blood pressure was measured using mercury sphygmomanometers and cuffs that covered at least $80 \%$ of the distance between the shoulder and the olecranon process and the total circumference of the right arm, after resting for 5 minutes and in a sitting position. Values were expressed as the average result of three measurements.

Risk factors in family members (father, mother and grandparents [males younger than 55 years old and females younger than 65 years]) were obtained based on a written questionnaire, and specifically counting all cases of obesity, type 2 diabetes, HTN, dyslipemia, and ischemic heart disease and stroke events.

\section{Criteria used for the diagnosis of overweight and obesity, and arterial hypertension}

Overweight was defined as a weight above the 85 th percentile, moderate obesity, as a weight above the $95^{\text {th }}$ percentile, and severe obesity, as a weight above the $97^{\text {th }}$ percentile, as per the Orbegozo Foundation's tables (Bilbao). ${ }^{10}$

Normal arterial pressure values were those below the $90^{\text {th }}$ percentile; values were considered normal-high if systolic blood pressure (SBP) and diastolic blood pressure (DBP) were above the 90th percentile and below the $95^{\text {th }}$ percentile, or if they were above $120 / 80 \mathrm{~mm} / \mathrm{Hg}$ in three measurements, even if below the $90^{\text {th }}$ percentile; values were modified according to the guidelines issued by the European Society of Hypertension (ESH), the European Society of Cardiology (ESC), the National High Blood Pressure Education
Program Working Group on High Blood Pressure in Children and Adolescents of the American Academy of Pediatrics, and the reference values obtained from the RICARDIN II study. ${ }^{11-12}$

\section{RESULTS}

One thousand and twenty one athletic children and adolescents aged 6-16 years old were included: 911 (71\% males, 29\% females) from Santoña, and 110 (92\% males, 8\% females) from Almería. Differences in body variables were eliminated when analyzing data as a global sample, not comparable between both sites (Table 1).

A total of $226(22.1 \%, 95 \%$ CI: $19.6-24.8 \%)$ patients with overweight or obesity as an individual factor and 21 (2.1\%, 95\% CI: $1.2-3.1 \%)$ patients with hypertension were detected.

In relation to the association of family risk factors with the child's weight, the cumulative prevalence by disease ranged between 0 and up to 4 family members with dyslipemia or hypertension per child, with no significant differences observed (Table 2). There were no differences when comparing the percentage of ancestors with risk factors, either (Table 3).

Percentages of obesity came up as an isolated family risk factor in the maternal

TABLE 1. Anthropometric characteristics of studied children

\begin{tabular}{lcccccc}
\multirow{2}{*}{$\begin{array}{l}\text { Outcome } \\
\text { measures }\end{array}$} & \multicolumn{3}{c}{ Site $\mathbf{1}(\boldsymbol{n}=\mathbf{9 1 1})$} & \multicolumn{3}{c}{ Site $\mathbf{2}(\boldsymbol{n}=\mathbf{1 1 0})$} \\
\cline { 2 - 7 } & Mean & SD $^{*}$ & IC95\% & Mean & SD $^{*}$ & IC95\% \\
\hline Age (years) & 9.7 & 3.4 & $9.5-9.9$ & 12.3 & 3 & $11.7-12.9$ \\
Weight $(\mathrm{kg})$ & 38.4 & 15.4 & $37.4-39.4$ & 56.4 & 21.1 & $52.4-60.4$ \\
Height $(\mathrm{m})$ & 1.38 & 0.2 & $1.37-1.40$ & 1.6 & 0.19 & $1.56-1.63$ \\
Body mass & & & & & & \\
index $\left(\mathrm{kg} / \mathrm{m}^{2}\right)$ & 18.9 & 3.2 & $18.7-19.1$ & 21.2 & 4.38 & $20.4-22.1$ \\
\hline
\end{tabular}

* DE: desviación estándar.

IC95\%: intervalo de confianza del 95\%.

TABLE 2. Family members with cardiovascular risk factors per child

\begin{tabular}{lccc}
\hline $\begin{array}{l}\text { Cardiovascular } \\
\text { risk factor }\end{array}$ & $\begin{array}{c}\text { Family members per child with } \\
\text { overweight-obesity (n: 226) } \\
\text { median (range) }\end{array}$ & $\begin{array}{c}\text { Family members per child with } \\
\text { normal weight (n: 795) } \\
\text { median (range) }\end{array}$ & $p$ value \\
\hline Obesity & $0(0-2)$ & $0(0-3)$ & $\mathrm{p}=0.2491$ \\
Type 2 diabetes & $0(0-2)$ & $0(0-3)$ & $\mathrm{p}=0.5186$ \\
Dyslipemia & $0(0-4)$ & $0(0-3)$ & $\mathrm{p}=0.9625$ \\
Arterial hypertension & $0(0-3)$ & $0(0-4)$ & $\mathrm{p}=0.4781$ \\
\hline
\end{tabular}


line (grandmother and grandfather) of obese patients: $30 \%, 95 \%$ CI: $24.1-36.5 \%$ and $26 \%$, 95\% CI: $20-31.8 \%$, respectively. There were significant differences $(\mathrm{p}<0.001)$ when comparing the percentage of obesity recorded in most ancestors (father, mother, paternal and maternal grandmother and grandfather) and athletic patients with a marked weight excess (Table 4).

\section{DISCUSSION}

The detection of cardiovascular risk factors in children and their family members has been the subject of multiple studies conducted in the general pediatric population for the primary or secondary prevention of CVD..$^{1-3}$ The amount of similar research work in athletic children has been scarce, unlike studies in adult athletes, who have a more frequent rate of sudden death or other CVDs, and usually have one or more risk factors, such as increased BMI and HTN. ${ }^{8}$

Capella, et al. analyzed obesity in athletic children, but no precise numbers regarding this issue were defined.6 In our sample, the percentage of obesity was $22.1 \%$, similar to what has been described in the general spanish pediatric population.

The relevance of detecting obesity lies on that, although it does not constitute a contraindication against practicing a sport, it predisposes individuals to complications such as hypertension, increased cardiac mass and other risks that entail certain precautions should be taken. ${ }^{4,6,14}$

A limitation of our study was the use of the BMI as the single method officially accepted to classify weight level, without making an anthropometric indirect estimation of body fat or fat free mass, as in other studies in children soccer players. ${ }^{15}$

HTN was described as a factor associated with the risk of sudden death and arrhythmias in professional athletes, ${ }^{5}$ and it was the second most important individual risk factor detected in 21 of our patients. Similar publications in athletic children are limited. . $^{4,7,9}$ One of them makes an association among hypertension, obesity and the potential development of sustained hypertension in $80 \%$ of athletes who had hypertension at the beginning of the season. ${ }^{7}$ Detecting HTN allows to adapt their type and level of training so that they avoid a higher cardiac overload.

Looking for a family risk factor associated with the presence of ICVRFs, as an element of future exposure to CVDs, which has been extensively analyzed in non-athletic children, has not been specifically looked into athlete subsets.

TABLE 3. Proportion of family members with cardiovascular risk factors

\begin{tabular}{lccc} 
Family members with CVRF & Children with overweight/obesity $(\mathbf{n}=\mathbf{2 2 6})$ & Children with normal weight (n= 795) & $p$ \\
\hline Fathers & $51(23 \%, 95 \%$ CI: $17-28.5)$ & $160(20 \%, 95 \%$ CI: $17-23)$ & 0.479 \\
Mothers & $35(15 \%, 95 \%$ CI: $11-20.8)$ & $103(13 \%, 95 \%$ CI: $10.6-15.4)$ & 0.383 \\
Paternal grandfathers & $53(23 \%, 95 \%$ CI: $18-29.5)$ & $177(22 \%, 95 \%$ CI: $19.4-25.3)$ & 0.774 \\
Paternal grandmothers & $34(15 \%, 95 \%$ CI: $10.6-20.3)$ & $161(20 \%, 95 \%$ CI: $17.5-23.2)$ & 0.096 \\
Maternal grandfathers & $66(29 \%, 95 \%$ CI: $23.3-35.6)$ & $210(26 \%, 95 \%$ CI: $23.3-29,6)$ & 0.454 \\
Maternal grandmothers & $73(32 \%, 95 \%$ CI: $26.2-38.3)$ & $231(29 \%, 95 \%$ CI: $25.9-38.3)$ & 0.390 \\
\hline
\end{tabular}

CVRF: Cardiovascular risk factors.

TABLE 4. Proportion of obese family members

\begin{tabular}{lcrr}
\hline Obese family members & Children with overweight/obesity $(\mathbf{n = 2 2 6 )}$ & Children with normal weight $(\mathbf{n =} 795)$ & $p$ \\
\hline Fathers & $41(18 \%, 95 \%$ CI: $13.3-23.8)$ & $3(0 \%, 95 \%$ CI: $0-1.10)$ & $<0.0001$ \\
Mothers & $35(15 \%, 95 \%$ CI: $11-20.8)$ & $8(1 \%, 95 \%$ CI: $0.4-1.9)$ & $<0.0001$ \\
Paternal grandfathers & $46(20 \%, 95 \%$ CI: $15.2-26.2)$ & $1(0 \%, 95 \%$ CI: $0-0.07)$ & $<0.0001$ \\
Paternal grandmothers & $27(12 \%, 95 \%$ CI: $8-16.9)$ & $3(0 \%, 95 \%$ CI: $0-1.10)$ & $<0.0001$ \\
Maternal grandfathers & $58(26 \%, 95 \%$ CI: $20-31.8)$ & $8(1 \%, 95 \%$ CI: $0.4-1.9)$ & $<0.0001$ \\
Maternal grandmothers & $68(30 \%, 95 \%$ CI: $24.1-36.5)$ & $8(1 \%, 95 \%$ CI: $0.4-1.9)$ & $<0.0001$ \\
\hline
\end{tabular}


Doing exercise regularly, indicated to fight obesity and hypertension, does not prevent the potential development of both conditions in young athletes or their family members, and can be easily detected through a medical exam as the one used in this study.

Other limitations of the study are that this sample is not representative of the population of interest, there was no control group of nonathletes and, given the study's retrospective nature, data were collected from the available medical records, which can be restricted or incomplete.

\section{CONCLUSIONS}

Out of 1021 athletic children and adolescents, 226 were obese and 21 had hypertension. Obesity was the most relevant isolated family factor on the mother's side (grandmother and grandfather) of obese subjects: $30 \%$ and $26 \%$, respectively. There were significant differences $(\mathrm{p}<0.001)$ among all obese ancestors and athletic patients.

\section{Acknowledgments}

To Nora Inés Castiglia, M.D. specialized in scientific advice from the Teaching and Research Department of Hospital Bernardino Rivadavia, Buenos Aires, Argentine. Executive Director of www.consumaciencia.com.ar.

\section{BIBLIOGRAPHY}

1. Rongling L, Alpert B, Walker S, Somes G. Longitudinal relationship of parental hypertension with body mass index, blood pressure and cardiovascular reactivity in children. J Pediatr 2007;150:498-502.

2. Chen W, Srinivasan S, Bao W, Berenson G. The magnitude of familial associations of cardiovascular risk factor variables between parents and offspring are influenced by age: the Bogalusa Heart Study. Ann Epidemiol 2001;11:522-8.
3. Díaz Martín JJ, Málaga Diéguez I, Argüelles Luis J, Diéguez Junquera $\mathrm{M}$, et al. Agrupamiento de factores de riesgo cardiovascular en hijos obesos de padres con hipertensión esencial. An Pediatr (Barc) 2005;63(3):238-43.

4. Rice S, Council on Sports Medicine and Fitness. Alteraciones médicas que afectan a la participación en el deporte. Pediatrics (edesp) 2008;65(4):210-8.

5. Kaplan N, Gidding S, Pickering T, Phil D, Wright J. Task Force 5: Systemic hypertension. JACC 2005;45(8):1346-8.

6. Capella M, Butcher Mokha M. Obesity in athletics: Part I. Athletic Therapy Today 2005.Pág.28-9.

7. Leddy J, Izzo J. Hypertension in athletes. J Clin Hypertens 2009;11:226-33.

8. Tucker A, Vogel R, Lincoln A, Dunn R, et al. Prevalence of cardiovascular disease risk factors among national football league players. JAMA 2009;301(20):2111-19.

9. Demorest R, Washington R and Council on Sports Medicine and Fitness. Athletic participation by children and adolescents who have systemic hypertension. Pediatrics 2010(125):1287-94.

10. Sobradillo B, Aguirre A, Aresti V, Bilbao A, et al. Curvas y tablas de crecimiento (estudios longitudinal y transversal). En: Libro de la Fundación Faustino Orbegozo Eizaguirre. Madrid: Ergon Ediciones; 2004. Págs.7-31.

11. Grupo cooperativo español para el estudio de factores de riesgo cardiovascular en la infancia y la adolescencia. Factores de riesgo cardiovascular en la infancia y la adolescencia en España. Estudio RICARDIN II: Valores de referencia. An Esp Pediatr 1995;43:11-17.

12. The fourth report on the diagnosis, evaluation, and treatment of high blood pressure in children and adolescents. National High Blood Pressure Education Program Working Group on High Blood Pressure in Children and Adolescents. Pediatrics 2004;114(Sup 2):555-76.

13. Rubio M, Salas-Salvadó J, Barbany M, Moreno B, et al. Consenso SEEDO 2007 para la evaluación del sobrepeso y la obesidad y el establecimiento de criterios de intervención terapéutica (versión íntegra). Sociedad Española para el Estudio de la Obesidad. Rev Esp Obes 2007. Págs 7-48.

14. Harris K, AlSaloos H, DeSouza A, SanataniS, etal. Biophysical properties of the aorta and left ventricle and exercise capacity in obese children. Am J Cardiol 2012;110:897-901.

15. Moreno L, León J, Serón R, Mesana M, Fleta J. Body composition in young male football (soccer) players. Nutrition Research 2004;(24):235-42. 